\title{
Targeting Child Labor in Debt Bondage: Evidence, Theory, and Policy Implications
}

\author{
Arnab K. Basu and Nancy H. Chau
}

\begin{abstract}
Despite recent multilateral efforts to single out child labor in debt bondage as one of the worst forms of child labor, several important questions have yet to be addressed: How pervasive is the phenomenon? Are there systematic correlations between the incidence of children in debt bondage and the economic, legislative, and financial development indicators of the economy? How does an understanding of these correlates affect the way national and international policy measures aimed at targeting this form of child labor are perceived? This article addresses each of these questions. The empirical findings suggest strong correlation between the likelihood of the incidence of child labor in debt bondage with the stage of development of an economy, the stage of financial development, and enforcement of core labor rights. Building on this evidence, the article presents a theoretical model that highlights the drawbacks and merits of a number of policies aimed at putting checks on child labor in debt bondage.
\end{abstract}

The call to abolish child labor in debt bondage is of long standing. As early as 1956, the United Nations Supplementary Convention on the Abolition of Slavery outlawed the institution of debt bondage. ${ }^{1}$ More recently, the 1999 adoption of the International Labour Organization (ILO) Convention on the Worst Forms of Child Labor aroused renewed interest in coordinating international actions to address the plight of children whose labor is pledged against outstanding household debt.

Arnab K. Basu is Assistant Professor, Department of Economics, College of William and Mary; his e-mail address is akbasu@wm.edu. Nancy H. Chau is Associate Professor, Department of Applied Economics and Management, Cornell University; her e-mail address is hyc3@cornell.edu. The authors are indebted to François Bourguignon for his insightful comments, which greatly improved the article. They also thank Kaushik Basu, Judith Dean, Alec Fyfe, Bjorne Grimsrud, Frank Hagerman, Andy Horowitz, Raja Kali, Furio Rosati, and Zafiris Tzannatos and participants at the conference on the Economics of Child Labour in Oslo in May 2002 for helpful comments and suggestions. The article also benefited from the suggestions and detailed comments of two anonymous referees. The authors finished the article while in residence at the Department of Economics and Finance at the City University of Hong Kong. The hospitality of the department staff and colleagues is gratefully acknowledged.

1. The 1956 Convention defines debt bondage as "the status or condition arising from a pledge by a debtor of his personal services or of those of a person under his control as security for a debt, if the value of those services as reasonably assessed is not applied towards the liquidation of the debt or the length and nature of those services are not respectively limited and defined.”

DOI: $10.1093 /$ wber/lhg020

(C) 2003 The International Bank for Reconstruction and Development / THE WORLD BANK 
A number of international policy actions have been put in place to liberate children and poor households from debt bondage. These include law enforcement efforts, such as the training of inspectors to enforce child labor laws (IPEC 1997), and direct actions that assist governments and local nongovernmental organizations to liberate children from debt bondage and to provide education, small business loans, and other forms of assistance (InFocus Programme 2002). ${ }^{2}$ A number of extranational initiatives are also in effect that condition international trade benefits on the extent of child labor and bonded labor practices. $^{3}$

Despite these developments, the incidence of child labor in debt bondage remains an open question, along with its possible economic, legislative, and structural correlates on a cross-national basis. The first objective of this article is to provide a preliminary examination of the available evidence. In particular, how pervasive is the phenomenon of child labor in debt bondage? Are there systematic correlations between the incidence of children in debt bondage and indicators of economic, legislative, and financial development? Perhaps more important, how do national and international policy measures aimed at targeting this form of child labor fare once the phenomenon is understood in the context of a country's stage of economic, legislative, and financial development? 4

Available cross-national evidence on the incidence of child labor in debt bondage is used to construct an index of the incidence of child labor in debt bondage for 163 countries. The data also cover respect for core labor rights (such as freedom of association and the right to organize); indicators of financial development and access to credit (interest rate gap, share of private credit to gross domestic product (GDP), and an estimated country-specific coefficient of consumption smoothing); macroeconomic variables; and country fixed factors.

The findings suggest systematic correlations between the incidence of child labor in debt bondage and the enforcement of core labor rights and the stage of development of an economy. Although the financial development indicators are

2. In November 2000 the ILo launched a $\$ 3.5$ million program to achieve the sustainable liberation of an estimated 75,000 men, women, and children in Nepal from bonded labor.

3. See USTR (1997) for a listing of General System of Preference (GSP) suspensions, partial suspensions, and reviews and Brenton (2000) for the GSP conditionality of the European Union. Further, Basu and others (2000) examine the effectiveness of product labeling programs aimed at promoting trade without inducing additional child labor employment.

4. For studies of interlinked credit-labor arrangements, see Braverman and Stiglitz (1982), Bardhan (1989), Basu (1987), Braverman and Srinivasan (1982), and Sadoulet (1992) and Genicot (2002). These studies highlight the efficiency implications of such arrangements, as when alternative sources of credits or insurance other than the landlord are not available or when the need to repay outstanding debt creates incentive to work that are otherwise absent. In this article the role of child labor in debt bondage is introduced explicitly, and the relative merits and drawbacks of policy interventions in terms of child labor employment and household welfare are emphasized. 
at best imperfect proxies for the degree of access to consumption smoothing by agrarian households, countries with positive incidence of child labor in debt bondage nevertheless appear to have, on average, lower levels of financial sector development. In addition, child labor in debt bondage is found to be particularly prevalent in countries where agriculture is the mainstay economic activity.

Somewhat surprisingly, there is little cross-national evidence suggesting significant correlation of the incidence of child labor in debt bondage and the application of minimum age legislation to employment in agriculture. Indeed, in developed and developing economies alike, child labor in agriculture is frequently exempt from national minimum age legislation.

These findings form the building blocks of the theoretical model set out here. It identifies poverty and the absence of reliable legal and financial systems through which the poor can secure loans to safeguard against hunger or unexpected consumption needs as root causes of child labor in debt bondage. ${ }^{5}$ Consequently, child labor in debt bondage grows out of an institutional arrangement in which labor and credit contracts are interlinked and outstanding household debts are paid at least in part through the labor services of children.

The basic framework extends Basu and Chau (2002) and highlights the principal-agent problem confronting landlords-moneylenders and agrarian households. ${ }^{6}$ The findings illustrate how agrarian households respond to the need to service outstanding debts and to finance subsistence consumption by putting children to work. ${ }^{7}$

Four classes of policy actions are considered for eliminating child labor in debt bondage: enforcement of minimum age laws, direct transfers to remove children and agrarian households from bondage, alternative sources of credit, and alternative sources of employment during periods of low income. Two themes emerge from the examination of these policy options. Policy measures strong enough to eradicate debt bondage do not necessarily result in a lower incidence of child labor. Policy interventions should be evaluated based on

5. See, for example, Rosenzweig (1981), Grootaert and Kanbur (1995), Basu and Van (1999), and Grote and others (1999).

6. This article departs from Basu and Chau (2002) in two regards. First, the need to fulfill subsistence consumption is shown to be vital to child labor supply and to the equilibrium prevalence of debt bondage contracts. Second, this article also examines the effectiveness of a host of policy measures aimed at eradicating the institution of debt bondage.

7. Grote and others (1999) and Baland and Robinson (2000) study child labor in a context of credit market imperfections that put limits on education undertakings. The appeal of removing children from the workforce thus lies in overcoming the undersupply of educated laborers. Although this article also takes credit market imperfection as a starting point, child labor is a by-product of the principal-agent decision problem facing landlords and households. As will become clear, the policy implications found to be effective are accordingly those that tip the balance of the principal-agent relationship in favor of households. 
whether they tilt the principal-agent link in favor of households rather than landlords and enhance outside options for households.

For example, efforts to enforce minimum age legislation have a direct negative impact on the demand price for child labor. Consequently, debt bondage becomes less attractive to landlords not because household demand for consumption smoothing is any less but because their ability to service outstanding debts during the harvest season is lower with tighter enforcement. So, although strict enforcement of child labor laws may well eradicate debt bondage, there is little guarantee that the incidence of child labor will decline (particularly when the need to finance subsistence consumption is important enough) or that household welfare will improve.

The second policy option addresses the supply side of the market for child labor in debt bondage. The analysis spells out how the availability of options outside the household and the well-being of households that choose to remain free of debt bondage are key determinants of the equilibrium terms of the creditlabor service contract between landlords and households. Any direct transfers that target only households in bondage, leaving the welfare of other households unaltered, have no impact on the equilibrium incidence of child labor in debt bondage. In fact, once landlords and households fully anticipate the possibility of direct transfers into the terms of the interlinked contract, not only will the equilibrium child labor incidence remain unaffected but landlords will effectively be the sole beneficiaries of any direct transfers that are intended for the indebted households.

The next two policy options explore the effectiveness of providing alternative source of credit and employment at times of poor labor market outcomes. As expected, the availability of an alternative source of credit curbs the implicit interest rate that landlords can charge and can completely replace debt bondage as a source of credit when interest rates are sufficiently low. However, little stands in the way of households that respond to easy credit terms by borrowing even more. Indeed, if the provision of alternative credit sources is the only policy to combat debt bondage, the incidence of child labor will always rise as households service the increase in debts by putting children to work in the spot labor market. The provision of productive labor employment opportunities has the virtue that it addresses both the consumption needs of poor households during periods of low income and households' need to put children to work. Indeed, productivity-enhancing lean season employment and the ensuing rise in adult productivity (and hence adult income) in the harvest season are key factors that contribute to ending the institution of debt bondage and child labor.

Thus, although the main findings are consistent with recent international efforts aimed at combating debt bondage, they also caution against wholesale implementation of policy measures without due consideration of the specific features of debt bondage. The following section presents the data and provides an account of the economic, legislative, and financial development characteristics 
of countries with bonded child labor. Section II presents the basic theoretical model, section III turns to an examination of the policy implications of the theoretical setup, and section IV presents concluding comments.

\section{Cross-National Evidence on Debt Bondage}

With few exceptions, there are no precise cross-national estimates of the incidence of child labor in debt bondage. ${ }^{8}$ An admittedly crude measure of the incidence of child labor in debt bondage was constructed using an indicator variable bondchild, where a value of one is assigned whenever incidences of child labor in debt bondage have been reported and a value of zero otherwise. The information on which the indicator is based comes from Country Report on Human Rights Practices for 1998 (U.S. Department of State 1999) and the Worldwide Report on the Worst Forms of Child Labor (Global March against Child Labour 2000).

Table 1 summarizes the relevant statements in the Country Report on Human Rights Practices for 1998 pertaining to Bulgaria, India, Iraq, and the United States and the corresponding values of bondchild assigned to each country. ${ }^{9}$ A potential drawback of relying solely on descriptive reports, however, is that data may be missing on the incidence of debt bondage in high-income countries. This potential sample bias is addressed by assigning countries to the bondchild $=0$ group whenever the incidence of child labor (aged 10-14) is reported as zero based on the ILo data on economically active population adopted in the World Development Indicators (World Bank 2001). Table 2 lists the 163 countries included in the data set.

Three indicators are used to address whether a country adequately observes core labor rights. One deals with national legislation regarding the treatment of child labor in agriculture. The indicator variable legexag is constructed for each country and assigned a value of one whenever child agricultural labor is exempt from national minimum age legislations, as reported in ILO (2001). A second indicator variable, enforce, deals with the enforcement of core labor rights, based on the four-point scores in Organisation for Economic Co-operation and Development (OECD) (2000). ${ }^{10}$ It takes a value of zero for the two groups of countries in which enforcement of freedom of association and the right to

8. The exceptions include India, Nepal, and Pakistan, for which some information on the extent of child labor in debt bondage is available from estimates of government and nongovernmental organizations. It bears emphasis that data from difference sources tend to differ by wide margins. See, for example, Basu and Chau (2002) for an account of available survey evidence on all three countries.

9. To focus on the source country of debt bondage, observations of bonded child labor that involves the smuggling of children from another country are excluded. The United States is a case in point.

10. The question remains, however, of how to measure the enforcement of core labor rights (see, for example, Chau and Kanbur 2002). 
TABLe 1. Human Rights Report Entry

\begin{tabular}{llc}
\hline Country & \multicolumn{1}{c}{ Statements } & Bondchild \\
\hline Bulgaria & "Cases of forced or bonded labour have not been reported." & 0 \\
India & "An estimated 15 million children are working under bondage." & 1 \\
Iraq & "No information about forced child labour is available." & - \\
United States & "Alien smuggling organizations using & \\
& $\begin{array}{l}\text { Suriname as an intermediate destination } \\
\text { to smuggle Chinese nationals, including women } \\
\\
\end{array}$ & and girls, into the United States, where frequently they are \\
& forced into bonded labour situations." \\
\hline
\end{tabular}

Source: U.S. Department of State (1999); Global March against Child Labor (2000).

organize is deemed adequate and a value of one for the two groups of countries in which more severe violations have been reported (OECD 2000). ${ }^{11}$ The final indicator is an outcome measure that gives the share of economically active children aged 10-14 (World Bank 2001). ${ }^{12}$

Ideally, the indicator of credit market imperfection would capture the ease of access to consumption smoothing loans for poor agrarian households. However, in the absence of an obvious candidate that measures the size and scope of informal credit markets, three other indicators were constructed or taken from various sources. The variable intspread captures the average gap between official lending rate and the deposit rate during 1994-98 (World Bank 2001). The variable priv denotes the share of private credit (by deposit money banks and other financial institutions) to GDP (Beck and others 2000). A third indicator attempts to measure the development of insurance markets by estimating the extent to which variability in gross domestic product per capita $\left(\Delta \log y_{i t}\right)$ translates into variability in household consumption per capita $\left(\Delta \log c_{i t}\right)$ (1970-98, constant 1995 prices). Data on GDP and household consumption per capita are from World Bank (2001). For each country $i$, the variable riskshare is taken to be the estimated least squares regression coefficient $\beta_{i}$ of the following regression equation:

$$
\Delta \log c_{i t}=\gamma_{i}+\beta_{i} \Delta \log y_{i t}+\epsilon_{i t} .
$$

When $\beta_{i}$ takes on a value of zero, household consumption is fully insured from per capita income shocks in country $i$. When $\beta_{i}=1$, there is perfect pass-through of income variability to household consumption variability.

11. The variable enforce is constructed in this way because there are, for example, only four countries in our data set that have the lowest labor standard score based on OECD (2000). The logit estimations later in the article accordingly contain outcomes that could have been completely determined had the fourpoint classification simply been adopted as dummy variables.

12. There is also a burgeoning literature on the determinants of child labor (see, for example, Rogers and Swinnerton 2002). 
TABLE 2. Incidence of Child Labor in Debt Bondage

\begin{tabular}{|c|c|c|c|c|c|c|c|}
\hline \multirow{2}{*}{\multicolumn{2}{|c|}{$\frac{\text { Bondchild }=1}{\text { Countries list }}$}} & \multicolumn{6}{|c|}{ Bondchild $=0$} \\
\hline & & \multicolumn{6}{|c|}{ Countries list } \\
\hline 1 & Angola & 44 & Albania & 88 & Greece & 132 & Rwanda \\
\hline 2 & Bangladesh & 45 & Algeria & 89 & Guinea & 133 & St Kitts and Nevis \\
\hline 3 & Benin & 46 & Andorra & 90 & Guyana & 134 & St Lucia \\
\hline 4 & Bolivia & 47 & $\begin{array}{l}\text { Antigua and } \\
\text { Barbuda }\end{array}$ & 91 & Hong Kong & 135 & $\begin{array}{l}\text { St Vincent \& } \\
\text { Grenadines }\end{array}$ \\
\hline 5 & Brazil & 48 & Argentina & 92 & Iceland & 136 & Samoa \\
\hline 6 & Burkina Faso & 49 & Armenia & 93 & Ireland & 137 & Sao Tome \& Principe \\
\hline 7 & Burma & 50 & Australia & 94 & Israel & 138 & Saudi Arabia \\
\hline 8 & Cambodia & 51 & Austria & 95 & Italy & 139 & Senegal \\
\hline 9 & Cameroon & 52 & Azerbaijan & 96 & Jamaica & 140 & Seychelles \\
\hline 10 & Chad & 53 & Bahamas & 97 & Japan & 141 & Singapore \\
\hline 11 & Colombia & 54 & Bahrain & 98 & Kazakhstan & 142 & Slovakia \\
\hline 12 & Comoros & 55 & Barbados & 99 & Kiribati & 143 & Slovenia \\
\hline 13 & Cote d'Ivoire & 56 & Belarus & 100 & Korea, Dem. & 144 & Solomon Islands \\
\hline 14 & Dominican Rep. & 57 & Belgium & 101 & Korea, Rep. & 145 & Spain \\
\hline 15 & Gabon & 58 & Belize & 102 & Kuwait & 146 & Suriname \\
\hline 16 & Ghana & 59 & Bhutan & 103 & Kyrgyzstan & 147 & Sweden \\
\hline 17 & Haiti & 60 & Botswana & 104 & Latvia & 148 & Switzerland \\
\hline 18 & India & 61 & Bulgaria & 105 & Lesotho & 149 & Syria \\
\hline 19 & Indonesia & 62 & Burundi & 106 & Liechtenstein & 150 & Tajikistan \\
\hline 20 & Kenya & 63 & Canada & 107 & Lithuania & 151 & Tonga \\
\hline 21 & Laos & 64 & Cape Verde & 108 & Luxembourg & 152 & Trinidad \& Tobago \\
\hline 22 & Lebanon & 65 & $\begin{array}{l}\text { Central African } \\
\text { Rep. }\end{array}$ & 109 & Macau & 153 & Tunisia \\
\hline 23 & Liberia & 66 & Chile & 110 & Madagascar & 154 & Turkmenistan \\
\hline & Malawi & 67 & China & 111 & Malaysia & 155 & Ukraine \\
\hline 25 & Mali & 68 & Congo & 112 & Maldives & 156 & UAE \\
\hline 26 & Mauritania & 69 & Costa Rica & 113 & Malta & 157 & United Kingdom \\
\hline 27 & Morocco & 70 & Croatia & 114 & Marshall Islands & 158 & USA \\
\hline 28 & Mozambique & 71 & Cuba & 115 & Micronesia & 159 & Uzbekistan \\
\hline 29 & Namibia & 72 & Cyprus & 116 & Moldova & 160 & Vanuatu \\
\hline 30 & Nepal & 73 & Czech Rep. & 117 & Monaco & 161 & Venezuela \\
\hline 31 & Nicaragua & 74 & Denmark & 118 & Mongolia & 162 & Yemen \\
\hline 32 & Nigeria & 75 & Dominica & 119 & Netherlands & 163 & Yugoslavia \\
\hline 33 & Pakistan & 76 & Ecuador & 120 & New Zealand & & \\
\hline 34 & Peru & 77 & Egypt & 121 & Norway & & \\
\hline 35 & Philippines & 78 & El Salvador & 122 & Oman & & \\
\hline 36 & Sierra Leone & 79 & Eq. Guinea & 123 & Palau & & \\
\hline 37 & South Africa & 80 & Eritrea & 124 & Panama & & \\
\hline 38 & Sri Lanka & 81 & Estonia & 125 & Papua New Guinea & & \\
\hline 39 & Sudan & 82 & Fiji & 126 & Paraguay & & \\
\hline 40 & Thailand & 83 & Finland & 127 & Poland & & \\
\hline 41 & Togo & 84 & France & 128 & Portugal & & \\
\hline 42 & Uganda & 85 & Gambia & 129 & Qatar & & \\
\hline 43 & Vietnam & 86 & Georgia & 130 & Romania & & \\
\hline & & 87 & Germany & 131 & Russian Federation & & \\
\hline
\end{tabular}

Note: The countries in bold are classified bondchild $=0$ based on the child labor data in World Bank (2001).

Source: U.S. Department of State 1999; Global March Against Child Labor 2000; World Bank 2001. 


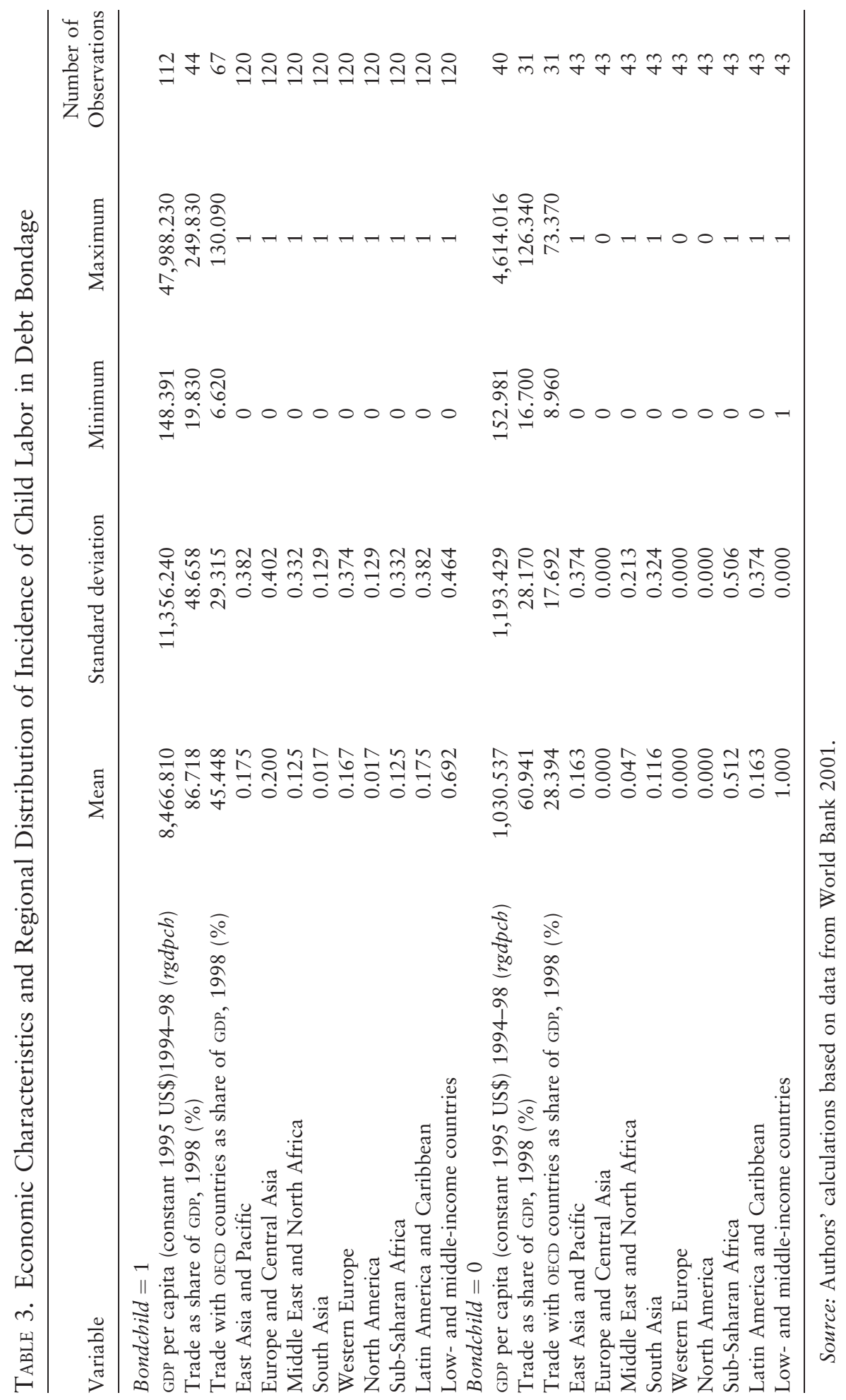


Table 3 presents summary statistics on the basic macroeconomic characteristics and the regional distribution of countries with and without reported incidences of child labor in debt bondage. Child labor in debt bondage is reported in 43 of the 163 countries for which data are available. As expected, child labor in debt bondage is a developing economy phenomenon, although approximately 69 percent of countries free of observed incidence of child labor in debt bondage are in fact low- and middle-income countries (World Bank 2001). In addition, debt bondage is nonexistent in countries with mean GDP per capita (1994-98) greater than $\$ 4,614$. This is similar to the findings in Krueger (1997), which show a threshold income level dividing countries with and without reported incidences of child labor. Table 3 also shows that countries with debt bondage exhibit weaker trade links with the rest of the world and with OECD countries.

Table 4 presents information on the dependence on agriculture of the two groups of countries. Close to 40 percent of countries with reported incidence of child labor in debt bondage are exporters of nonfuel primary products, with agricultural exports contributing more than 50 percent to total export revenue. In contrast, a core group of countries without child labor in debt bondage are manufactures exporters. Despite these observed differences in trade patterns, the value added of agricultural workers is significantly higher in countries in which debt bondage does not exist.

With respect to the adoption of core labor standards in the two groups of countries, the average share of economically actively children (aged 10-14) is substantially higher in countries where child labor in debt bondage is reported (table 5). This is despite the fact that almost all of the countries included in the data set have signed international conventions or adopted national minimum age legislation. Respect for the rights of workers to negotiate wages and form unions is observed much more in countries without observed child labor in debt bondage. Somewhat surprising, however, is that legislative exceptions for child labor in agriculture are common, regardless of whether debt bondage is reported or not.

On the degree of financial market development, it appears that countries with child labor in debt bondage have on average a larger interest rate gap and a lower share of private credit issued by deposit money banks and other financial institutions (table 6). In addition, countries without reports of child labor in debt bondage also tend to perform better on the ability of the average household to smooth consumption in the face of income shocks.

Tables 7 and 8 present logit estimates of the marginal impact of three factors that contribute to an increase in the likelihood of child labor in debt bondage. ${ }^{13}$

13. The number of observations used in these estimations is different as country coverage differs across data sources on labor standards, financial development, and other variables. A check of the frequency distribution of countries with child labor in debt bondage for each of the independent variables for which data are available found the percentages to be relatively stable, ranging from 2.2 percentage points above to 4.4 percentage points below the overall reported incidence of children in debt bondage (43 out of 163 countries). 


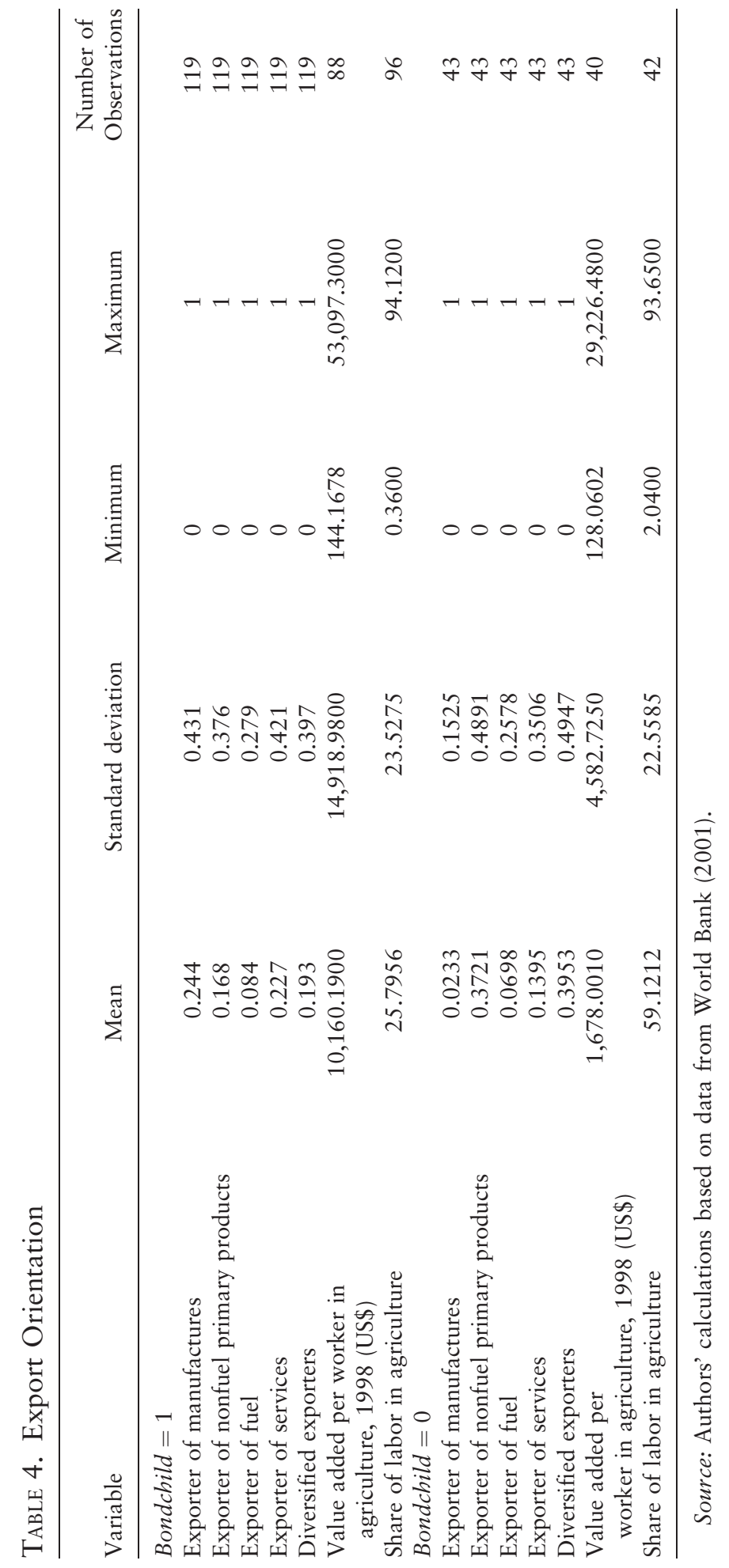


TABle 5. Observance of Core Labor Standards

\begin{tabular}{lccccc}
\hline Variable & Mean & $\begin{array}{c}\text { Standard } \\
\text { deviation }\end{array}$ & Minimum & Maximum & $\begin{array}{c}\text { Number of } \\
\text { Observations }\end{array}$ \\
\hline $\begin{array}{l}\text { Bondchild =1 } \\
\begin{array}{l}\text { Child labor (\% of } \\
\text { children aged 10-14) }\end{array}\end{array}$ & 5.535 & 11.893 & 0.000 & 52.670 & 101 \\
$\begin{array}{l}\text { legexag } \\
\text { enforce }\end{array}$ & 0.691 & 0.465 & 0 & 1 & 68 \\
$\begin{array}{l}\text { Bondchild = } \\
\begin{array}{l}\text { Child labor (\% of } \\
\text { children aged 10-14) }\end{array}\end{array}$ & 0.178 & 0.387 & 0 & 1 & 45 \\
$\begin{array}{l}\text { legexag } \\
\text { enforce }\end{array}$ & 0.741 & 13.376 & 0.000 & 52.490 & 43 \\
\hline
\end{tabular}

Source: Authors' calculations based on data from World Bank (2001); ILO (2001); OECD (2000).

These factors include a stage of economic development variable (average real GDP per capita, 1994-98), variables indicating observance of basic core labor rights (enforce and legexag), and a stage of financial development indicator. Although results vary in magnitude and significance, child labor in debt bondage is less likely in countries where per capita real income is relatively high, the rights of workers to freely negotiate wages and form unions are respected, and financial markets are better developed. ${ }^{14}$ Not surprisingly, because exceptions to child labor in agriculture are common in developing

TABLE 6. Financial Development and Credit Markets

\begin{tabular}{lrrrrc}
\hline Variable & Mean & $\begin{array}{c}\text { Standard } \\
\text { deviation }\end{array}$ & Minimum & Maximum & $\begin{array}{c}\text { Number of } \\
\text { Observations }\end{array}$ \\
\hline $\begin{array}{l}\text { Bondchild }=1 \\
\text { intspread }(\%)\end{array}$ & 9.265 & 10.741 & 1.203 & 75.160 & 78 \\
risksharegdp & 0.772 & 0.645 & -1.389 & 3.422 & 87 \\
priv $(\%)$ & 48.930 & 35.094 & 5.163 & 166.201 & 45 \\
Bondchild $=0$ & & & & & \\
intspread $(\%)$ & 12.034 & 9.766 & -3.026 & 42.286 & 22 \\
risksharegdp & 1.024 & 0.705 & -0.050 & 4.476 & 34 \\
priv $(\%)$ & 24.436 & 18.716 & 2.766 & 74.398 & 18 \\
\hline
\end{tabular}

Source: Authors' calculations based on data from Beck and others (2000) and World Bank (2001).

14. As will be shown later, the institution of debt bondage has the effect of raising the total incidence of child labor. As such, the empirical results here are consistent with Dehejia and Gatta (2002), who find the cross-country empirical relationship between financial development and child labor incidence to be positive. In addition, Guarcello and others (2002) similarly show that credit rationing and income shocks are important determinants of child labor in Guatemala. 
Table 7. Logit Regression: Debt Bondage, Stage of Development, Core Labor Rights, and Financial Development

\begin{tabular}{|c|c|c|c|c|c|}
\hline & I & II & III & IV & V \\
\hline $\operatorname{lrg} d p p c$ & $\begin{array}{c}-1.1560^{*} \\
(0.25)\end{array}$ & $\begin{array}{c}-1.5829 * \\
(0.43)\end{array}$ & $\begin{array}{c}-0.926^{* * *} \\
(0.19)\end{array}$ & $\begin{array}{c}-1.2643^{*} \\
(0.28)\end{array}$ & $\begin{array}{c}-1.1568 * \\
(0.25)\end{array}$ \\
\hline intspread & $\begin{array}{c}-0.0175 \\
(0.03)\end{array}$ & & & & \\
\hline priv & & $\begin{array}{l}3.5480 \\
(1.80)\end{array}$ & & & \\
\hline riskshare & & & $\begin{array}{l}0.3687 \\
(0.37)\end{array}$ & & \\
\hline enforce & & & & $\begin{array}{l}0.9351 \\
(0.90)\end{array}$ & \\
\hline legexag & & & & & $\begin{array}{c}-0.3157 \\
(0.60)\end{array}$ \\
\hline Constant & $\begin{array}{l}7.3430 * \\
(1.88)\end{array}$ & $\begin{array}{l}9.6952 * \\
(2.62)\end{array}$ & $\begin{array}{l}5.4576 \text { * } \\
(1.32)\end{array}$ & $\begin{array}{l}8.5447^{*} \\
(2.41)\end{array}$ & $\begin{array}{l}7.5945 * \\
(1.83)\end{array}$ \\
\hline$N$ & 99 & 63 & 121 & 59 & 94 \\
\hline Wald chi $^{2}$ & 22.1500 & 20.2300 & 25.3700 & 23.9000 & 22.6600 \\
\hline Prob $>$ chi $^{2}$ & 0.0000 & 0.0000 & 0.0000 & 0.0000 & 0.0000 \\
\hline Pseudo $R^{2}$ & 0.2605 & 0.3890 & 0.2383 & 0.4279 & 0.3143 \\
\hline Log likelihood & -37.8318 & -23.0276 & -54.7395 & -18.4945 & -38.0124 \\
\hline
\end{tabular}

*Significant at the $1 \%$ level.

Note: Dependent variable is the incidence of child labor in debt bondage (bondchild). Numbers in parentheses are robust standard errors.

Source: Authors' calculations based on data from U.S. Department of State (1999); Global March against Child Labor (2000); World Bank (2001); ILO (2001); OECD (2000); and Beck and others (2000).

and developed economies, the coefficients on legexag (table 8) are insignificant and of the wrong sign. ${ }^{15}$

These observations motivate three main features of the model. To begin with, poverty is viewed as one of the root causes of child labor, with the need to finance subsistence consumption a key rationale for putting children to work. Second, agrarian households are taken to have no access to formal credit markets, and consumption smoothing over periods of low income is available only through local landlords-moneylenders. Accordingly, the interlinked transactions examined take the form of a credit-labor service contract. Finally, agrarian workers have limited ability to organize and collectively negotiate the terms of the interlinked contracts with employers. This may be due to standard free-rider concerns or legal exceptions to child labor laws and union activities in agriculture. The next section shows how the emergence and persistence of the

15. As a robustness check, a logit estimation was also conducted using the restricted data set that leaves out the 10 observations with bondchild $=0$ that are based on World Bank (2001). The signs and significance of estimated coefficients remain unchanged. These results are available on request. 
Table 8. Logit Regression (Continued): Debt Bondage, Stage of Development, Core Labor Rights, and Financial Development

\begin{tabular}{|c|c|c|c|c|c|c|}
\hline & I & II & III & IV & V & VI \\
\hline $\operatorname{lrg} d p p c$ & $\begin{array}{l}-1.1272 * \\
(0.65)\end{array}$ & $\begin{array}{l}-2.3113 * * * * \\
(0.86)\end{array}$ & $\begin{array}{l}-1.4130 * * * \\
(0.32)\end{array}$ & $\begin{array}{l}-1.3590 * * * \\
(0.35)\end{array}$ & $\begin{array}{l}-2.2187 \% * * \\
(0.62)\end{array}$ & $\begin{array}{l}-1.0311^{* * *} \\
(0.24)\end{array}$ \\
\hline intspread & $\begin{array}{l}0.2802 * \\
(0.16)\end{array}$ & & & $\begin{array}{c}-0.0098 \\
(0.03)\end{array}$ & & \\
\hline priv & & $\begin{array}{l}4.6499 \\
(2.89)\end{array}$ & & & $\begin{array}{l}4.2044 \\
(2.70)\end{array}$ & \\
\hline riskshare & & & $\begin{array}{l}2.6290 * \\
1.51\end{array}$ & & & $\begin{array}{c}-0.0978 \\
0.61\end{array}$ \\
\hline enforce & $\begin{array}{l}3.7249 * * \\
(1.59)\end{array}$ & $\begin{array}{l}1.6429 \\
(1.31)\end{array}$ & $\begin{array}{l}0.5646 \\
(1.00)\end{array}$ & & & \\
\hline legexag & & & & $\begin{array}{c}-0.7129 \\
(0.83)\end{array}$ & $\begin{array}{l}-2.1337^{*} \\
(1.07)\end{array}$ & $\begin{array}{l}0.0093 \\
(0.67)\end{array}$ \\
\hline Constant & $\begin{array}{l}3.3707 \\
(6.32)\end{array}$ & $\begin{array}{l}14.4978 * * * \\
(5.77)\end{array}$ & $\begin{array}{l}8.0873 * * * \\
(2.43)\end{array}$ & $\begin{array}{l}9.3724 * * * \\
(2.76)\end{array}$ & $\begin{array}{l}15.4856 * * * \\
(3.97)\end{array}$ & $\begin{array}{l}6.6209 * * * \\
(1.88)\end{array}$ \\
\hline$N$ & 45 & 43 & 54 & 66 & 51 & 81 \\
\hline Wald chi ${ }^{2}$ & 17.5100 & 17.6800 & 24.6600 & 18.2700 & 21.1000 & 19.0600 \\
\hline Prob $>$ chi $^{2}$ & 0.0006 & 0.0005 & 0.0000 & 0.0004 & 0.0001 & 0.0003 \\
\hline Pseudo $R^{2}$ & 0.5810 & 0.6019 & 0.4843 & 0.3638 & 0.5195 & 0.2709 \\
\hline Log likelihood & -8.8241 & -8.7814 & -15.9377 & -23.2569 & -14.4032 & -34.5402 \\
\hline
\end{tabular}

"Significant at the $10 \%$ level.

* *Significant at the $5 \%$ level.

***Significant at the $1 \%$ level.

Note: Dependent variable is the incidence of child labor in debt bondage (bondchild). Numbers in parentheses are robust standard errors.

Source: Authors' calculations based on data from U.S. Department of State (1999); Global March against Child Labor (2000); World Bank (2001); ILO (2001); OECD (2000); and Beck and others (2000).

institution of child labor in debt bondage can be understood with these features in place.

\section{The Basic Model}

The basic model scrutinizes the interactions between landlords-moneylenders and agrarian households during the two seasons of an agricultural year-a lean season during which a spot labor market does not exist and a harvest season during which landlords compete in hiring wage laborers (Bardhan 1983; Basu 2002). Total harvest season output of a representative landlord is taken to be $X=\omega \mathrm{L}$, where $\mathrm{L}$ denotes labor input, and $\omega$ the marginal product of labor. ${ }^{16}$ Adult and child laborers are imperfect substitutes in harvest work, and each unit of child labor is equivalent to $0<a<1$ of adult labor. The spot market returns

16. See Basu and Chau (2002) for a presentation of the intricacies that arise when production is more generally of the decreasing marginal product variety. 
to a unit of adult labor and child labor are thus $\omega$ and $a \omega$, respectively, in units of agricultural output.

Each laborer household supplies (inelastically) one unit of adult labor. It may also supply up to one unit of child labor depending on labor market conditions and household consumption needs. Let $\bar{C}$ denote the per season subsistence consumption of the household, and $B_{0}$ the inherited savings that the household can draw on to sustain consumption during the lean season. The utility of a household depends on net above subsistence-level household consumption each season $\left(c^{l}-\bar{C}, c^{b}-\bar{C}\right)$, child labor $\left(\ell^{k}\right)$, and savings of harvest income to cover any above-subsistence-level consumption during the next lean season $\left(B_{1}\right):^{17}$

(2) $u=\log \left(c^{l}-\bar{C}\right)+\rho\left[\alpha \log \left(c^{b}-\bar{C}\right)+(1-\alpha) \log \left(1-\ell^{k}\right)\right]+\rho^{2} \log \left(B_{1}-\bar{C}\right)$,

where $0 \leq \alpha \leq 1$ is the preference weight attached to consumption in the harvest season relative to the cost of putting the child to work, ${ }^{18}$ and $\rho$ is the subjective discount factor per season.

\section{Households in the Absence of Debt Bondage}

Inherited savings $B_{0}$ is taken as given. Let $y^{o}(\omega) \equiv \omega(1+a)-2 \bar{C}$ denote the disposable full income of the household during the harvest season, after accounting for expenditures on subsistence consumption during the harvest season and the upcoming lean season. Also let $b_{0}=b\left(B_{0}, y^{o}\right)$ be the ratio of inherited disposable savings to full disposable income $\left(B_{0}-\bar{C}\right) / y^{o}(\omega)$. As will become clear, $b_{0}$ parameterizes the vulnerability of households to borrowing from landlords and engaging in debt bondage. In particular, it can be readily verified that if $b_{0}$ is sufficiently small, so that $\rho(1+\rho) b_{0}<1$, households with no access to credit are better off consuming their entire available budget during the lean season.

The household then faces two budget constraints, one for the lean season and one for the harvest seasons: ${ }^{19}$

$$
c^{l}=B_{0}, \quad c^{b}=\omega\left(1+a \ell^{k}\right)-B_{1} .
$$

The utility maximizing level of child labor during the harvest season is given by:

17. Note that if households are assumed to ignore subsistence consumption needs in the future, then the implied savings can dip below the subsistence level, and debt bondage contracts trivially prevail, allowing landlords to extract the harvest income of the household completely without violating individual rationality.

18. While not explicitly modeled, $1-\alpha$ can be interpreted more generally as the disutility of child labor, which may be due to time away from school or hazardous labor.

19. The section on Voluntary Participation in Debt Bondage also shows that unless $\rho(1+\rho) b_{0}$ is less than unity, debt bondage will be a nonissue in equilibrium, even if landlords face minimal opportunity cost of loans $(i=0)$. 
Figure 1. Child Labor Supply and Debt Bondage

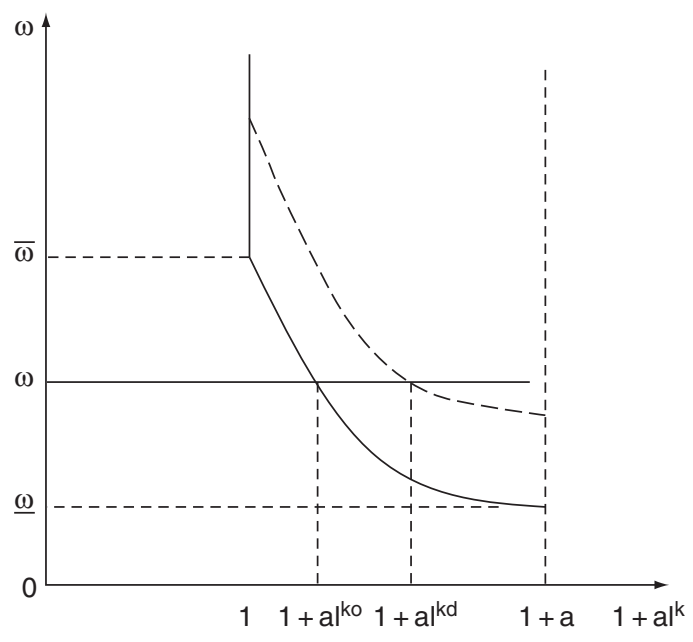

$$
\left.\ell^{k o}=\min \left\{1, \max \left\{0,1-\left[(1-\alpha) y^{o}(\omega)\right]\right\} /[(1+\rho) \alpha \omega]\right\}\right\} .
$$

There is thus a positive incidence of child labor if the disutility of child labor $(1-\alpha)$ is not too large, child and adult laborers are close substitutes, ${ }^{20}$ and adult wage income $\omega$ is small relative to subsistence consumption needs $\bar{C}$.

Equation 4 implies a downward-sloping labor supply schedule. In figure 1, $\bar{\omega}$ denotes a threshold level of adult labor income such that $\ell^{k o}(\omega)=0$ for all $\omega \geq \bar{\omega}$. In addition, if $\omega \leq \underline{\omega}$, child labor supply is similarly independent of small changes in the spot wage, as the household deploys all available adult and child labor time to fulfill subsistence consumption needs. ${ }^{21}$ Because the primary focus here is child labor, $\omega$ is taken to be in the range $(\underline{\omega}, \bar{\omega})$. The child labor supply of a household free from debt bondage is thus given by $\ell^{k o}=1-\left[(1-\alpha) y^{o}(\omega)\right] /[(1+\rho) a \omega]$, and utility is then given by

$$
V^{o}\left(B_{0}\right)=\log \left(B_{0}-\bar{C}\right)+\rho(1+\rho) \log y^{o}(\omega)+K
$$

in which $K$ is a constant.

20. It can be shown that the lower limit on $a$ is given by $a /(1+a)>(1-a) /(1+\rho)$.

21. $\bar{\omega}$ is given by $[2(1-\alpha) \bar{C}] /[(1-\alpha)(1+a)-(1+\rho) a]$ and $\underline{\omega}$ by $2 \bar{C} /(1+a)$. 


\section{Households Engaged in Debt Bondage}

The landlord has the option of providing lean season consumption loans to laborer households. ${ }^{22}$ In exchange for a loan of $D$ amount to supplement lean season consumption, the household repays the landlord $\bar{\ell}$ amount of effective labor during the harvest season, where $\bar{\ell}$ can be made up of child labor, adult labor, or a combination. Unless $\bar{\ell}$ amount of effective labor services is repaid in full, the household may not search for harvest season employment elsewhere.

Debt bondage alters the household decision problem directly through the lean and harvest season budget constraints:

$$
c^{l}=B_{0}+D, \quad c^{b}=\omega\left(1+a \ell^{k}-\bar{\ell}\right)-B_{1} .
$$

For households engaged in debt bondage, let superscript $d$ denote utility maximizing levels. Debt bondage will apply whenever $B_{0}$ is binding in the no-debt situation, that is, $\rho(1+\rho) b_{0}<1$. Given the debt repayment obligation, child labor becomes greater and more likely when outstanding debts are positive. In that case child labor is given by

$$
\ell^{k d}=1-\left[(1-\alpha)\left(y^{o}(\omega)-\omega \bar{\ell}\right)\right] /[(1+\rho) a \omega]=\ell^{k o}+(1-\alpha) \bar{\ell} /[(1+\rho) a] .
$$

Thus, child labor supply rises with debt obligations. In figure 1, the labor supply schedule of households engaged in debt bondage thus lies uniformly above that of households free of debt bondage. Utility in this case is given by

$$
V^{d}\left(B_{0}, D, \bar{\ell}\right)=\log \left(B_{0}+D-\bar{C}\right)+\rho(1+\rho) \log \left(y^{o}(\omega)-\omega \bar{\ell}\right)+K,
$$

where $K$ is the same constant as previously mentioned.

\section{Voluntary Participation in Debt Bondage}

With the option of participating in debt bondage open to individual households, voluntary participation in debt bondage requires that $V^{d}\left(B_{0}, D, \bar{\ell}\right) \geq V^{o}\left(B_{0}\right)$. Combining the preceding expressions of utility functions, voluntary participation requires that

$$
D \geq\left(B_{0}-\bar{C}\right)\left\{\left[y^{o}(\omega-\omega \bar{\ell}) / y^{o}(\omega)\right]^{-\rho(1+\rho)}-1\right\}=D\left(\bar{\ell}, B_{0}\right),
$$

where where $D\left(\bar{\ell}, B_{0}\right)$ represents the minimum loan necessary to induce participation given $\bar{\ell}$. represents the minimum loan necessary to induce participation

22. Following Hart (1986) and Binswanger and Rosenzweig (1984), the model takes into account established patron-client relationships between landlords and households, in which the prevalence of a caste system or past employment history, for example, dictate the size and the identity of the pool of households from which reliable labor services and debt repayments can be ensured. 
given $\bar{\ell}$. As may be expected, it is increasing and strictly convex in $\bar{\ell}$, implying therefore that the cost that a landlord must incur in the form of a lean-season consumption loan increases with the amount of labor services demanded as payment. Intuitively, as the need for consumption smoothing declines with higher levels of $B_{0}$, the loan cost required to induce participation likewise increases, so that $D\left(\bar{\ell}, B_{0}\right)$ is also increasing in $B_{0}$.

The decision problem of the landlord in the lean season involves the selection of $\bar{\ell}$ and $D$ for each borrowing household so as to maximize profits:

$$
\Pi=\max _{\bar{\ell}}\left[\omega \bar{\ell}-(1+i) D\left(\bar{\ell}, B_{0}\right)\right],
$$

where $i$ is the interest rate faced by the landlord. Because $D(\bullet)$ is increasing and strictly convex, the problem has a unique interior solution, $\bar{\ell}^{d}$. It follows easily that

$$
\bar{\ell}^{d}=0
$$

if $\rho(1+\rho)(1+i) b_{0} \geq 1$, and

$$
\left[y^{o}(\omega)-\omega \bar{\ell}^{d}\right] / y^{o}(\omega)=\left[\rho(1+\rho)(1+i) b_{0}\right]^{1 /[1+\rho(1+\rho)]}
$$

in the opposite case.

Debt bondage is thus an equilibrium phenomenon only if $\rho(1+\rho)(1+i) b_{0} \leq 1$. The disposable full income of a bonded household during the harvest season is then

$$
y^{o}(\omega)\left[\rho(1+\rho)(1+i) b_{0}\right]^{1 /[1+\rho(1+\rho)]} .
$$

It can be checked that the implicit interest rate of the debt bondage contract, $i^{d}=\left(\omega \bar{\ell}^{d} / D\right)-1$, is larger than the interest rate, $i$, faced by the landlord. As could be expected, the implicit interest rate is strictly increasing with respect to the interest rate facing the landlord and decreasing with respect to the initial household savings, $b_{0}$. Furthermore, the incidence of child labor in debt bondage $\ell^{k d}$ decreases with both $i$ and $b_{0}$.

In summary, child labor in debt bondage is all the more likely when the implicit degree of credit market imperfection, $1 /[\rho(1+i)]$, is large enough and when the need for consumption smoothing $\left(1 / b_{0}\right)$ is sufficiently acute. In addition, easier credit terms facing landlords (a decrease in $i$ ) and rising demand for lean season consumption loans (a decrease in $b_{0}$ ) both contribute to increase the incidence of child labor in debt bondage.

These circumstances governing the equilibrium prevalence of debt bondage have long-run implications as well. It can be readily verified that debt obligations in indebted households adversely affect the size of savings for the upcoming lean season, $B_{1}$. All else equal, this strengthens the demand for lean-season 
consumption loans and thus the incentive to engage in debt bondage once again. Indeed, it can be shown that debt bondage is endemic and prevails in a stationary state where $B^{d}{ }_{0}=B^{d}{ }_{1}$, whenever the degree of credit market imperfection is sufficiently acute, or $\rho^{2}(1+i)<1 .{ }^{23}$

\section{Policy Implications}

This section examines the effectiveness of a number of policy options aimed at reducing child labor in debt bondage. It considers legislative solutions that target the demand side of the labor market, direct transfers to address the supply of child labor, alternative sources of consumption loans where there are credit market imperfections, and alternative sources of employment opportunities.

\section{Legislative Solutions}

The practical difficulties of enforcing a ban on child labor aside, it bears emphasis that a priori the enforcement of a ban can have two opposing effects on the incidence of child labor. To see this, let $0 \leq q<1$ denote the probability that a landlord is caught hiring child labor. The expected output and therefore the spot harvest wage of a child laborer is thus just $(1-q) a \omega \leq a \omega$. It follows that enforcing a ban on child labor in agriculture has a direct negative effect on the demand price for child labor. However, the adverse demand effect of the ban also translates into a reduction in the expected full household income in the harvest season. Full income is now $y^{o}{ }_{q}(\omega)=y^{o}(\omega)-a \omega q$, and the effect of raising the likelihood of discovery $q$ may thus be to reinforce the incentives for households to put children to work. In the absence of debt bondage, the effect of a (imperfect) ban on child labor is thus ambiguous, as shown by replacing $y^{o}(\omega)$ with $y^{o}(\omega)-a \omega q$ and $a$ with $a(1-q)$ in equation 7 .

For households engaged in debt bondage, a third effect is also in play. Households find themselves less vulnerable to debt bondage as child labor laws are enforced because their ability to repay falls with increasingly stringent enforcement against the use of child labor. To see this recall that the solution of the landlord's profit maximization problem in equation 11 yields $\bar{\ell}^{d}=0$, if $\rho(1+\rho)(1+i) b_{q} \geq 1$ and that

$$
\left[y^{o}(\omega)-a \omega q-\omega \bar{\ell}^{d}\right] /\left[y^{o}(\omega)-a \omega q\right]=\left[\rho(1+\rho)(1+i) b_{q}\right]^{1 /[1+\rho(1+\rho)]}
$$

in the opposite case, with

23. Although a full-fledged analysis of the dynamics of debt bondage is beyond the scope of this article, interested reader may verify that $B^{d}{ }_{1}-\bar{C}$ is simply a fraction of the harvest income of the household net of debt obligations, $\rho\left[y^{o}(\omega)-\omega \bar{\ell}^{d}\right] /(1+\rho)$. Because debt obligations in turn depend (negatively) on inherited savings (equation 13), it can be easily seen that $\rho^{2}(1+i)<1$ also ensures exactly one interior stationary state with $B^{d}{ }_{1}-\bar{C}=B_{0}-\bar{C}$, in which the cycle of debt bondage repeats itself. 


$$
b_{q}=\left[b_{0} y^{o}(\omega)\right] /\left[y^{o}(\omega)-a \omega q\right] .
$$

In the case in which there was debt bondage in the absence of the ban, $\rho(1+\rho)(1+i) b_{0}<1$, equation 15 shows that debt bondage ceases to be an equilibrium phenomenon for sufficiently large values of enforcement intensity, $q$. In addition, child labor may rise or fall with $q$ for households engaged in debt bondage depending on the relative values of $\bar{C}$ and the expected contribution of child labor $a \omega(1-q) .{ }^{24}$ Regardless of relative parameter values, however, it must be clear that the enforcement of child labor laws comes at the expense of household welfare, because raising $q$ effectively decreases the full harvest season wage income of the household.

\section{Direct Transfers to Indebted Households}

Direct transfers to indebted households are meant to have the effect of removing or reducing the size of the outstanding debt and thereby the need to put children to work to supplement household consumption. However, the limits to such transfers in liberating households from debt bondage should be equally apparent.

Suppose a lump sum $\delta$ is transferred to indebted households in the harvest season and that this transfer is fully anticipated by both landlords and households in the lean season. Then the transfer will be fully appropriated by the landlord and will have absolutely no effect on child labor among households engaged in debt bondage or on their welfare. Indeed, the participation constraint in debt bondage (equation 9 ) is such that households receive the reservation utility level of households that do not engage in debt bondage. But this utility level is independent of $\delta$.

As long as the availability of direct transfers is fully expected by landlords and households alike, the size of the transfer will be fully incorporated into the interlinked contract. Thus, any increase in $\delta$, in the absence of compensating increases in the lean/harvest season income of the reservation household, will be offset by a corresponding increase in the labor service demanded by the landlord, $\bar{\ell}$, and the welfare of an indebted household is exactly equal to the welfare of the reservation household given $B_{0}$. In effect, landlords' profits increase one for one with the amount of transfers to indebted household. All the while, the incidence of child labor remains strictly unaffected. ${ }^{25}$

24. Specifically, child labor supply increases whenever $2 \bar{C}>\omega+a \omega(1-q) /[1+\rho(1+\rho)]$. Clearly, this occurs only if adult income in the harvest season is not sufficient to cover annual subsistence consumption needs.

25. This finding remains robust even when household utility is more generally defined as any increasing and concave function of lean- and harvest-season consumption, child labor, and savings, so that the landlord's decision problem has a unique solution. The important thing to observe is that the landlord's decision problem when households expect to receive $\delta$ in direct transfers and pay $\omega \bar{\ell}$ in debt obligations is equivalent to one in which the landlord simply demands $\omega \tilde{\ell}=\omega(\bar{\ell}-\delta / \omega)$ of debt repayment without any transfers from the government. It is thus easy to see that landlords' profits increase one for one with the amount of transfers $\delta$, because $\omega \bar{\ell}$ must be just $\omega \widetilde{\ell}+\delta$. 


\section{Credit Market Solutions}

Because the lack of alternative sources of consumption loans is one of the root causes of debt bondage, the provision of alternative sources of credit would seem to be a natural course of policy action. For one thing, the mere option of borrowing from a source other than the landlord may tip the balance of the principal-agent relationship between landlords and agrarian households in the households' favor.

Thus, let $i_{A}$ be the interest rate that a credit agency offers to any household. Interest rate $i_{A}$ may be greater than the opportunity cost of loans facing landlords, $i$, if, for example, the relative risk of default or the cost of monitoring loan payments is biased against the credit agency (see, for instance, Bottomley 1975; Basu 1984). Interest rate $i_{A}$ can also be less than $i$ if the credit program is government-subsidized. In either case, if all households have access to credit at interest rate $i_{A}$, the lean and harvest season budget constraints are

$$
c^{l}+L_{A}=B_{0}, c^{b}=\omega\left(1+a \ell^{k}\right)-L_{A}\left(1+i_{A}\right)-B_{1},
$$

where $L_{A}$ denotes the size of the loan. Full disposable income during the harvest season $y_{A}^{o} \equiv \omega(1+a)-L_{A}\left(1+i_{A}\right)-2 \bar{C}$ is necessarily lower than full disposable income without credit access, $y^{O}(\omega)$, because of the loan repayment. It follows from equation 4 that child labor is more likely, and larger when strictly positive, than in the absence of credit. Moreover, child labor supply increases with small decreases in $i_{A}$ whenever $L_{A}>0$. As may be expected, easier credit terms encourage borrowing, and as such the need to put children to work during the harvest season to repay outstanding debt to the credit agency also rises. Of course, these observations do not imply that easier credit terms make households worse off. Indeed, it is easy to show that household welfare is an decreasing function of $i_{A}$ with the noncredit case corresponding to a prohibitively high value of $i_{A}$.

Turning now to the landlords' decision problem, equation 16 implies a revised participation constraint, where $V^{d}\left(B_{0}, D, \bar{\ell}\right) \geq V_{A}^{o}\left(B_{0}, \omega, i_{A}\right)$. Thus it may be shown that households will rely on market credit whenever $\rho(1+\rho)\left(1+i_{A}\right)$ $b_{0}<1$ and debt bondage ceases to prevail as an equilibrium outcome if $i_{A} \leq i$. Debt bondage may persist if $i_{A}>i$, but child labor supply in households engaged in debt bondage is less than in the absence of credit. Moreover, the provision of easier credit terms by the agency (a decrease in $i_{A}$ ) decreases child labor in a situation of debt bondage.

The provision of alternative credit sources may thus eradicate debt bondage if the interest rate charged by credit agencies is sufficiently low. But even here, the incidence of child labor may nevertheless rise as each household simply switches from landlord to credit agency as a source of credit, where relatively cheaper credit increases the desire to borrow, particularly for households that have the strongest need for consumption loans. Until debt bondage is completely eradicated, however, the provision of easier credit terms can indeed decrease the incidence of child labor in debt bondage and raise the welfare of all households. 


\section{Labor Market Solutions}

In the search for a policy remedy, the findings so far highlight the importance of accounting for the institutional context in which debt bondage takes place. In particular, attempts to supply an alternative credit source may fall short of ending child labor so long as lean-season consumption needs continue to be sufficiently acute. Meanwhile, subsidies that target indebted households fail to improve the plight of bonded households, as the terms of the interlinked contract are based on the availability of desirable outside options for households that elect not to participate in bondage.

These considerations suggest that a viable policy option should aim to reduce seasonal demand for credit and raise the welfare of the reservation households. To this end consider a rural public works program that provides employment opportunities during the lean season through activities such as irrigation, road construction, and other rural public goods that improve agricultural productivity. ${ }^{26}$ Such a program reduces the need for borrowing in the lean season and the need for child labor-because labor productivity is higher-in the harvest season.

More precisely, if the per worker payment that the rural public works program offers during the lean season is large enough, incentives for both households and employers to engage in debt bondage are eliminated. The equilibrium incidence of child labor in the harvest season decreases, and welfare rises for all households. Note, however, that to achieve all these favorable effects, rural public works programs might have to be substantially subsidized. The important point is that they are clearly superior to transfers that are conditional on debt.

\section{Long-Run Considerations and Policy Implications}

Finally, what are the longer-term implications of each of the four policies? To begin with, because the incidence of child labor in debt bondage is the joint outcome of consumption needs in the lean season and the lack of access to alternative credit (other than the landlord), the effect of any given policy may diminish over time. This occurs when the policy-induced change in the incidence of child labor is accomplished at the expense of reducing the household's ability to put aside harvest income for the next lean season. The enforcement of child labor laws fits squarely into this category as the harvest earnings of the household decline with the intensity of enforcement efforts. Thus a sustained increase in the intensity of enforcement of child labor laws can become increasingly ineffective, because households' need for lean-season consumption loans to subsidize the shortfall in savings becomes increasingly acute over time.

26. Such programs have taken on particular significance in South Asia in recent years. For an analysis, see Basu (2002). 
Consequently, even though enforcement may initially eradicate child labor, debt bondage will subsequently reemerge. ${ }^{27}$

It is also possible that the initial effect of policy actions on child labor in debt bondage may be weaker than the long-run response. This applies when policy actions lead to an increase in household savings, thus alleviating the need for child labor in debt bondage in subsequent years. The provision of easy credit and rural public works programs both fit this pattern. As long as debt bondage continues, easier credit directly lowers the debt obligations of households, whether they opt to borrow from landlords or from credit agencies. The incidence of child labor thus declines even further in subsequent years at constant $i_{A}$, as the credit policy enable households to put checks on the demand for loans in the future. Similarly, as long as debt bondage continues to prevail, the effectiveness of rural public works program in reducing the incidence of child labor is also stronger in subsequent periods. This is because lean-season employment and higher earnings in the harvest season enable households to save more for upcoming lean seasons.

These considerations are equally relevant to efforts to eradicate child labor in debt bondage. In particular, because there is no conflict between the initial impact and the dynamic consequences of easy credit and rural public works on the incidence of child labor induced by debt bondage, debt bondage does not reemerge in periods subsequent to the implementation of these two policy reforms. Tables 9 and 10 summarize these observations and highlight the initial impact and long-term effects of each of the four policies discussed so far.

\section{CONCLUSION}

This article began with an examination of the evidence on child labor in debt bondage, and this evidence was used to construct an index of bonded child labor. Broadly put, child labor in debt bondage is a developing economy phenomenon, although low income is not a sufficient condition for debt bondage. Also important are a dependence on agriculture as a mainstay economic activity, nonobservance of core labor rights, and underdeveloped insurance and financial markets.

Based on these observations, the theoretical model set out here seeks to answer several questions: Does debt bondage constitute an additional reason why children are put to work? Despite the fact that households "voluntarily" enter into interlinked contracts of debt and labor services, does bondage perpetuate poverty among agrarian households? Can debt bondage persist as a stable equilibrium outcome? The findings indicate that as long as the degree of

27. This reiterates the discussion earlier on how debt bondage will prevail in a stationary state whenever the degree of credit market imperfection is sufficiently acute $\left(\rho^{2}(1+i)<1\right)$, regardless of the degree of enforcement of the minimum age law. 


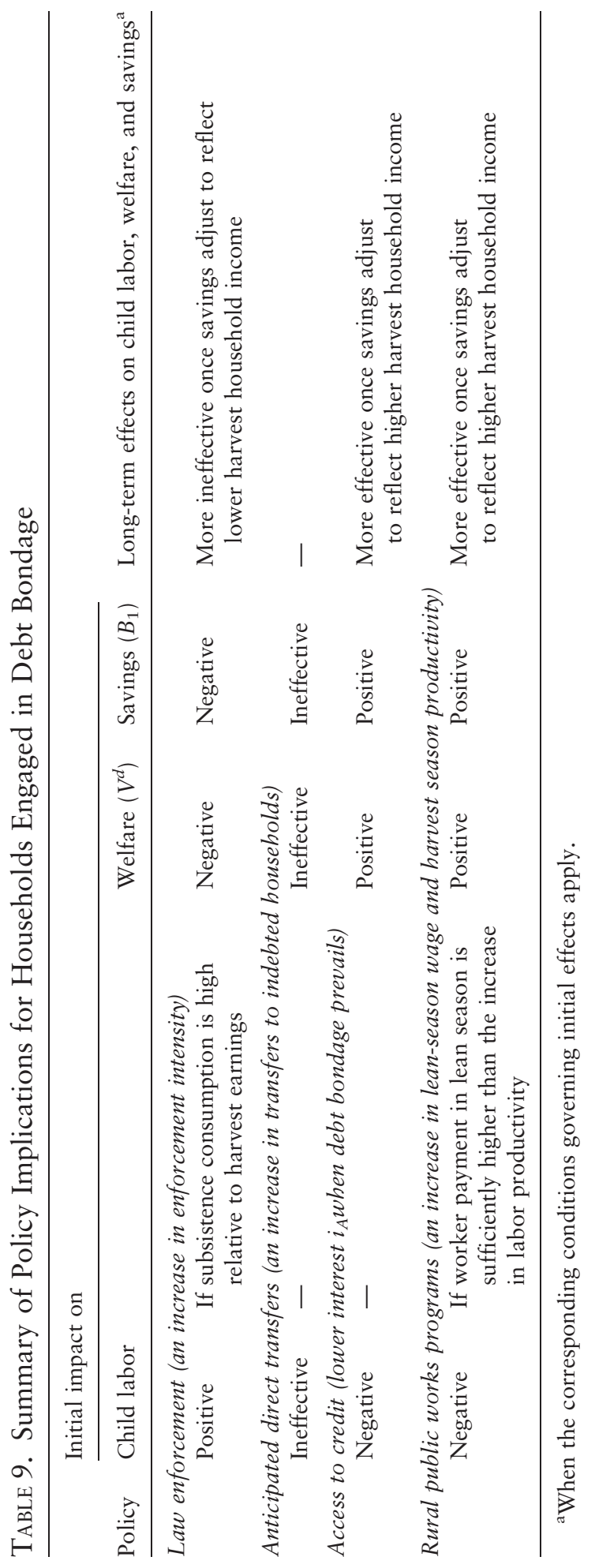




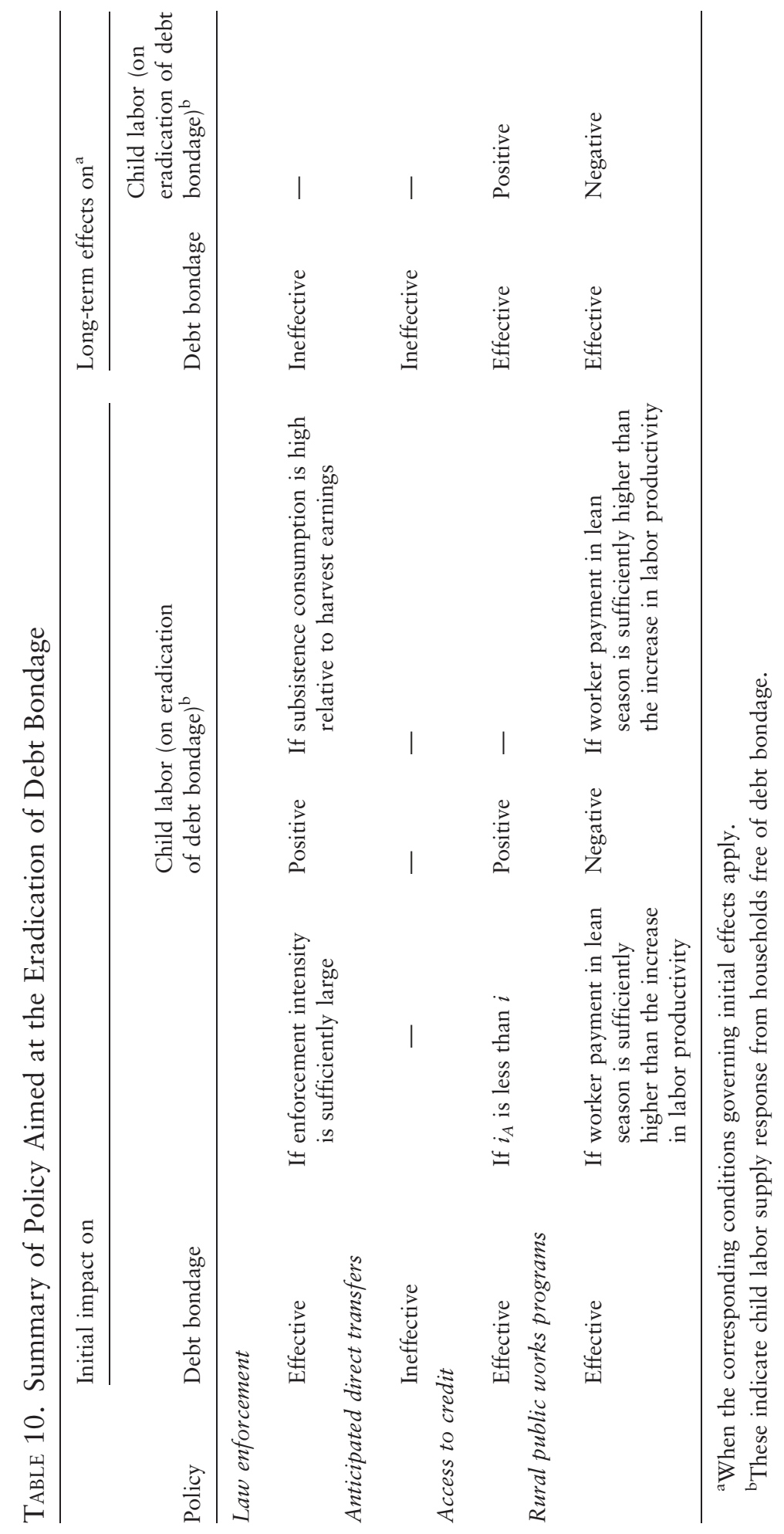


asymmetry in credit access is large enough, the answer to all three questions is yes. Debt bondage turns out to be an important feature in the cycle of poverty and child labor in agrarian economies.

These findings form the basis of the analysis of four types of policies aimed at combating child labor in debt bondage in poor agrarian in economies. In each case the merits and drawbacks of policy measures cannot be appropriately ascertained without accounting for the principal-agent relationship between households and landlords and the interplay between the need for consumption smoothing and the supply of child labor. Specifically, although standard demand-side disincentives, such as enforcement of minimum age laws, are expected to put checks on debt bondage, as households become less able to repay outstanding loans, the net outcome can in fact be an increase in child labor supply if, for example, subsistence consumption needs are sufficiently acute. Meanwhile, an examination of supplyside policies such as direct transfers to indebted households spells out the importance of understanding the institution of debt bondage as an implicit contract. Specifically, the welfare of households engaged in debt bondage depends critically on the availability of outside options. As such, discriminatory transfers that target solely indebted households have no impact on the equilibrium incidence of child labor.

An important theme that emerges is that the eradication of child labor in debt bondage need not imply the eradication of child labor. In particular, so long as lean-season consumption needs and low adult wages in the harvest season are not addressed, child labor supply may in fact increase as households switch from landlords as a credit source to other alternatives, particularly if the alternatives offer easier credit terms. Thus, although the basic empirical and theoretical conclusions in this article reiterate popular conceptions about the workings and welfare consequences of child labor arising out of bondage, the findings also caution against wholesale implementation of policy measures without due consideration of the institutional features specific to debt bondage.

\section{REFERENCES}

Baland, Jean-Marie, and James A. Robinson. 2000. "Is Child Labor Inefficient?" Journal of Political Economy 108(4):663-79.

Bardhan, Pranab K. 1983. "Labor-Tying in a Poor Agrarian Economy: A Theoretical and Empirical Analysis." Quarterly Journal of Economics 98:501-14.

—. 1989. "A Note on Interlinked Rural Economic Arrangements." In Pranab K. Bardhan, ed., The Economic Theory of Agrarian Institutions. Oxford: Oxford University Press.

Basu, Arnab K. 2002. "Oligopsonistic Landlords, Segmented Labor Markets and the Persistence of TiedLabor Contracts." American Journal of Agricultural Economics 84:438-53.

Basu, Arnab K., and Nancy H. Chau. 2002. "Exploitation of Child Labor and the Dynamics of Debt Bondage.” Working Paper 2002-06. Cornell University, Department of Applied Economics and Management, Ithaca, N.Y.

Basu, Arnab K., Nancy H. Chau, and Ulrike Grote. 2000. “Guaranteed Manufactured without Child Labor.” Working Paper 2000-04. Cornell University, Department of Applied Economics and Management, Ithaca, N.Y. 
Basu, Kaushik. 1984. "Implicit Interest Rates, Usury and Isolation in Backward Agriculture.” Cambridge Journal of Economics 8:145-59.

- 1987. "Disneyland Monopoly, Interlinkage and Usurious Interest Rates." Journal of Public Economics 34: 1-17.

Basu, Kaushik, and Pham Hoang Van. 1998. "The Economics of Child Labor." American Economic Review 88:412-27.

Beck, Thorsten, Asli Demirgüç-Kunt, and Ross Levine. 2000. "A New Database on the Structure and Development of the Financial Sector.” World Bank Economic Review 14: 597-605.

Binswanger, Hans P., and Mark R. Rosenzweig. 1984. Contractual Arrangements, Employment and Wages in Rural Labor Markets in Asia. New Haven, Conn.: Yale University Press.

Bottomley, Anthony. 1975. "Interest Rate Determination in Underdeveloped Rural Areas." American Journal of Agricultural Economics 57:279-91.

Braverman, Avishay, and T. N. Srinivasan. 1984. "Agrarian Reforms in Developing Rural Economies Characterized by Interlinked Credit and Tenancy Markets.” In Hans P. Binswanger and Mark R. Rosenzweig, eds., Contractual Arrangements, Employment, and Wage in Rural Labor Markets in Asia. New Haven, Conn.: Yale University Press.

Braverman, Avishay, and Joseph Stiglitz. 1982. "Sharecropping and the Interlinking of Agrarian Markets.” American Economic Review 72:695-715.

Brenton, Paul. 2000. "Globalisation and Social Exclusion in the Eu: Policy Implications.” CEPs Working Document No. 159. Centre for European Policy Studies, Brussels.

Chau, Nancy H., and Ravi Kanbur. 2002. "The Adoption of International Labor Standards: Who, When, and Why." Brookings Trade Forum, 2001. Washington, D.C.: Brookings Institution.

Dehejia, Rajeev, and Roberta Gatti. 2002. Child Labor: The Role of Income Variability and Access to Credit Across Countries. NBER Working Paper 9018. Bureau of Economic Research, Cambridge, Mass.

Genicot, Garance. 2002. "Bonded Labor and Serfdom: A Paradox of Voluntary Choice." Journal of Development Economics 67(1):101-27.

Global March against Child Labour. 2000. “A Worldwide Report on the Worst Forms of Child Labour.” Online document available at http://globalmarch.org/worstformsreport.

Grootaert, Christiaan, and Ravi M. Kanbur. 1995. "Child Labour: An Economic Perspective." International Labour Review 134(2):187-203.

Grote, Ulrike, Arnab K. Basu, and Diana Weinhold. 1999. "Child Labor and the International Policy Debate-The Education/Child Labor Trade-Off and the Consequences of Trade Sanctions." ZEF-Discussion Papers on Development Policy 1. Center for Development Research, Bonn.

Guarcello, Lorenzo, Fabrizia Mealli, and Furio Camillo Rosati. 2002. "Household Vulnerability and Child Labor: The Effect of Shocks, Credit Rationing, and Insurance.” Report for the Understanding Children's and Its Impact Project. ILO, World Bank, and United Nation's Children's Fund, Florence.

Hart, Gillian. 1986. "Interlocking Transactions: Obstacles, Precursors or Instruments of Agrarian Capitalism?” Journal of Development Economics 23:177-203.

IPEC (International Programme on the Elimination of Child Labour). 1997. Action against Child Labour: Lessons and Strategic Priorities for the Future A Synthesis Report. Geneva: International Labor Office.

InFocus Programme. 2002. Global Report under the Follow-up to the ilo Declaration on Fundamental Principles and Rights at Work: Stopping Forced Labour. Geneva: International Labour Office.

ILO (International Labour Office). 2001. Child Labor in Agriculture: A Survey of National Legislations. Geneva: International Labour Office.

Krueger, Alan. 1997. "International Labor Standards and Trade.” In Michael Bruno and Boris Pleskovic, eds., Annual World Bank Conference on Development Economics 1996. Washington, D.C.: World Bank.

Organization for Economic Cooperation and Development (OECD). 2000. "International Trade and Core Labor Standards.” Paris: Directorate for Employment Labor and Social Affairs, OECD. 
Roger, Carol Ann, and Kenneth A. Swinnerton. 2002. "Inequality, Productivity, and Child Labor: Theory and Evidence.” Working Paper. Department of Economics, Georgetown University, Washington D.C.

Rosenzweig, Mark R. 1981. "Household and Non-Household Activities of Youths: Issues of Modelling, Data, and Estimation Strategies." In Gerry Rodgers and Guy Standing, eds., Child Work, Poverty, and Underdevelopment. Geneva: International Labour Office.

Sadoulet, Elizabeth. 1992. "Labor-Service Tenancy Contracts in a Latin American Context." American Economic Review 82:1031-42.

U.S. Department of State, Bureau of Democracy, Human Rights, and Labor. 1999. Country Report on Human Rights Practices for 1998. Washington, D.C.

USTR (Office of the United States Trade Representative). 1997. "Monitoring and Enforcing Trade Laws and Agreements-Fact Sheet." Washington, D.C.

World Bank. 2001. World Development Indicators 2001. Washington, D.C. 
